\title{
Changes in breathing, swallowing and tongue position during treatment with functional elastic appliance in conjunction with myotherapy in the group of patients with malocclusion before growth spurt
}

\section{Zmiany zachodzące w czynności oddychania, połykania oraz pozycji języka podczas leczenia aparatem czynnościowym elastycznym w połączeniu z mioterapią w grupie osób przed skokiem wzrostowym z wadą zgryzu}

\section{Gabriela Urbaniak-Malinowska, Agata Niżankowska-Jędrzejczyk, Bartlomiej W. Loster}

Katedra Ortodoncii, Instytut Stomatologii, Wydział Lekarski, Uniwersytet Jagielloński Collegium Medicum, Kraków, Polska Chair of Orthodontics, Dental Institute, Faculty of Medicine, Jagiellonian University Medical College, Cracow, Poland Head: prof. B.W. Loster

\begin{abstract}
Introduction. Many activities such as chewing, swallowing, breathing, and speech, whose normal or abnormal functioning has a very significant impact on the development of dento-facial complex take place within the masticatory system. Numerous studies conducted on preschool children show a close correlation between the occurrence of abnormal function and maxillofacial complex defects on the one hand and the presence of malocclusions on the other. One of the most common dysfunctions is a dysfunction of the tongue, which is related to abnormal swallowing, and dysfunction related to mouth breathing.. Many researchers have noted a close correlation between the tongue or breathing dysfunction and the occurrence of certain malocclusions. The most common are: open bite, distoclusion, mesioclusion, and cross bite. Malocclusion resulting from dysunction can be treated by eliminating the disorders of the surrounding structures and by enabling their proper development. That is why it is important to eliminate these abnormal facial muscle dysfunctions and to enable the normal development of the dental arches as soon as possible. The earlier the return to correct function, the easier
\end{abstract}

\section{KEYWORDS:}

mouth breathing, tongue, myofunctional therapy, malocclusion

\section{Streszczenie}

Wstęp. Wukładzie stomatognatyczym odbywa się wiele czynności, takich jak żucie, połykanie, oddychanie, mowa, których przebieg prawidłowy lub nieprawidłowy ma bardzo istotny wpływ na rozwój kompleksu zębowo-twarzowego. Liczne badania dzieci w wieku przedszkolnym wskazuja na ścisła korelacje pomiędzy występowaniem nieprawidłowej funkcji $i$ zaburzeń kompleksu szczękowo-twarzowego a obecnościa wad zgryzu. Jedna z najczęstszych dysfunkcji jest dysfunkcja języka, związana $z$ nieprawidłowym potykaniem oraz oddychaniem przez usta. Wielu badaczy zauważa ścisłą korelację pomiędzy dysfunkcja języka czy oddychania a występowaniem określonych wad zgryzu. Do najczęstszych należy zgryz otwarty, tyłozgryz, przodozgryz $i$ zgryz krzyżowy. Wady zgryzu powstałe $w$ wyniku dysfunkcji można leczyć przez eliminację zaburzeń środowiska otaczającego $i$ poprzez umożliwienie prawidłowego rozwoju. Dlatego ważne jest jak najszybsze wyeliminowanie nieprawidłowych czynności mięśni twarzoczaszki $i$ umożliwienie prawidłowego rozwoju tuków zębowych. Im wcześniej powróci prawidłowa funkcja, tym łatwiej i szybciej, a nawet samoistnie bez terapii

\section{HAStA INDEKSOWE:}

oddychanie przez usta, iezzyk, mioterapia, wada zgryzu 
and faster, even spontaneously without orthodontic appliance therapy, the revocation of malocclusion formed on the background of dysfunction will be possible. Aim of the study. To analyse changes in breathing, swallowing and tongue position during treatment with standard functional elastic appliance with appropriate muscle exercises in children with the specified malocclusion (open bite, Class II/1) and dysfunction before peak of growth spurt. Material and method. Clinical trials were conducted in a group of ten patients aged 6 to 10 years, with milk or mixed dentition, before peak of growth spurt with the presence of at least one of the impaired functions of breathing, swallowing, and/or an abnormal position of the tongue during swallowing and with identified partial front open bite (overbite minimum of $-2 \mathrm{~mm}$ ) or Class II /1 malocclusion. The treatment consisted of the use of elastic functional appliance series EF Evolution of Orthoplus to re-educate the disturbed functions of swallowing and/or breathing. Results. After the treatment was completed all the patients reported improvement in competence of lips and in type of breathing. All children also noticed improvement in orbicular oris function during swallowing and its balance when closing the lips (no more excessive muscle contraction when trying to close the mouth) was reported by all study subjects. Significant changes among all patients in the activity of swallowing were noted. After re-education was completed in all the children with Class II/1, the tongue (during swallowing) could touch the lingual ridge of the maxillary alveolar process. Little or no improvement was noted in overbite dimension and tongue function in patients with skeletal open bite, which confirms the principle that in this group of patients tongue thrusting is the act of adaptation to the existing malocclusion, and it is necessary to ensure the front seal.

\section{Introduction}

The term dysfunction is understood as abnormal physiological functions, such as swallowing, breathing, chewing, speech, abnormal infant and child positioning during sleep and feeding, hypotonia and hypertonia of muscles and posture. Significance of dysfunction in the development of malocclusion can be found in many publications, some researchers even consider dysfunction as the primary etiological factor of malocclusion. $1,5,6,8$ aparatem ortodontycznym, możliwe jest cofnięcie sie wady zgryzu powstatej na tle dysfunkcji. Cel pracy. Celem badania była analiza zmian zachodzacych w czynności oddychania, polykania oraz pozycji języka podczas leczenia standardowym aparatem czynnościowym elastycznym typu Trainer wraz $z$ odpowiednimi ćwiczeniami mięśniowymi $w$ grupie dzieci przed skokiem wzrostowym, z określona wada zgryzu (zgryz otwarty, klasa II/1) i dysfunkcja. Material i metoda. Badania kliniczne zostaty przeprowadzone $w$ grupie 10 pacjentów $w$ wieku od 6 do 10 lat, $z$ uzębieniem mlecznym lub mieszanym, przed skokiem wzrostowym, $z$ występowanie przynajmniej jednej zaburzonej funkcji spośród funkcji oddychania, polykania i/lub nieprawidłowej pozycji języka w czasie polykania oraz ze stwierdzonym zgryzem otwartym częściowym przednim (szpara niedogryzowa minimum $2 \mathrm{~mm}$ ) lub wada klasy II/1. Leczenie polegato na zastosowaniu aparatu czynnościowego elastycznego $z$ serii EF Evolution firmy Orthoplus w celu reedukacji zaburzonych funkcji polykania lub/i oddychania. Wyniki. U wszystkich pacjentów po zakończonym leczeniu została poprawiona kompetencja warg oraz uzyskano poprawe $w$ sposobie oddychania. $U$ wszystkich dzieci zauważono poprawe $w$ funkcji mięśnia okrężnego ust $w$ trakcie polykania $i$ jego równowagę przy zamykaniu warg (brak nadmiernego skurczu mięśnia przy próbie zamykania ust). $U$ wszystkich pacjentów zauważono znaczace zmiany $w$ poprawie czynności polykania. Po zakończonej reedukacji u wszystkich dzieci z wada klasy II/1, język w czasie polykania prawidłowo kontaktowat sie na językowym stoku wyrostka zębodolowego szczęki. Zauważono nieznaczna lub brak poprawy wymiaru nagryzu pionowego oraz czynności języka u pacjentów ze zgryzem otwartym szkieletowym, co potwierdza zasadę, że w tej grupie pacjentów tloczenie języka jest czynnościa adaptacyjna do istniejacej wady $i$ jest konieczne $w$ celu zapewnienia uszczelnienia przedniego.

\section{Wstęp}

Pod pojęciem dysfunkcji rozumie się zaburzone czynności fizjologiczne, takie jak połykanie, oddychanie, żucie, mowa, nieprawidłowe układanie niemowlęcia i dziecka podczas snu i karmienia, hipotonia i hipertonia mięśni oraz wady postawy. W wielu publikacjach można odnaleźć istotne znaczenie dysfunkcji w powstawaniu wad zgryzu, a nawet niektórzy badacze uważają dysfunkcje za pierwotny czynnik etiologiczny wad zgryzu. $1,5,6,8$ 
Analysis of studies in nursery, preschool and school children showed that $80 \%$ of the maxillary occlusal disorder is caused by external factors, such as dysfunctions, parafunctions, systemic diseases and injuries within the craniofacial region. ${ }^{21,24,25}$ Malocclusion resulting from dysfunction can be treated by eliminating the disorders of the surrounding environment and by enabling proper development. It should be emphasized that the earliest possible diagnosis of disturbed function enables faster return to normal function. This kind of treatment is called re-education. During reeducation, simple orthodontic appliances, tailored to the type of dysfunction, are used: vestibular plates, Trainer-type elastic appliances, or other appliances for interceptive treatment combined with muscle exercises. Malocclusion resulting from morphogenetic and developmental defects is not subject to dysfunctional treatment. These cases require different therapeutic approaches. Early diagnosis by means of clinical observations and functional tests of these restrictions play a vital role while planning treatment. ${ }^{2}$

Many activities such as chewing, swallowing, breathing, speech, whose normal or abnormal functioning has a very significant impact on the development of dento-facial complex take place within the masticatory system. Apart from the aspect that concerns only teeth, one needs to be sure to treat the entire face as an individual unit. Numerous studies conducted on preschool children show a close correlation between the occurrence of abnormal function and maxillofacial complex defects with the presence of malocclusions. . $^{3,5,6,12,13,17,24,25}$ One of the most common dysfunctions is a dysfunction of the tongue which is related to abnormal swallowing $(50.2 \%)$ and dysfunction related to breathing through the mouth $(31.9 \%){ }^{3}$ Many researchers have noted a close correlation between tongue dysfunction and the occurrence of certain malocclusions. The most common are: open bite, distoclusion, mesioclusion. On the other hand, the relationship between deep bite and dental defects is less significant. The lowest dependency was observed in the transverse disorders. This is confirmed by numerous studies conducted by
Analiza przeprowadzonych badań u dzieci w wieku żłobkowym, przedszkolnym i szkolnym wykazała, że $80 \%$ zaburzeń szczękowo-zgryzowych jest spowodowana czynnikami zewnętrznymi, takimi jak: dysfunkcje, parafunkcje, choroby ogólne oraz urazy w obrębie twarzoczaszki. ${ }^{21,24,25}$ Wady zgryzu powstałe w wyniku dysfunkcji można leczyć przez eliminację zaburzeń środowiska otaczającego i poprzez umożliwienie prawidłowego rozwoju. Należy podkreślić, iż możliwe jak najwcześniejsze rozpoznanie zaburzonych funkcji, daje możliwość szybszego powrotu do prawidłowych funkcji. Jest to reedukacja. W reedukacji stosowane są odpowiednie, dostosowane do rodzaju dysfunkcji proste aparaty, m.in.: płytki przedsionkowe, aparaty elastyczne Trainery lub inne aparaty do leczenia interceptywnego wraz z ćwiczeniami mięśniowymi. Wady zgryzu powstałe na tle morfogenetycznymi i wad rozwojowych, nie podlegają leczeniu czynnościowemu. Te przypadki wymagają innego podejścia do leczenia. W planowaniu leczenia ważne jest wczesne wykrycie tych ograniczeń za pomocą obserwacji klinicznych i testów czynnościowych. $^{2}$

W układzie stomatognatyczym odbywa się wiele czynności, takich jak żucie, połykanie, oddychanie, mowa, których prawidłowy lub nieprawidłowy przebieg ma bardzo istotny wpływ na rozwój kompleksu zębowo-twarzowego. Pomijając aspekt dotyczący wyłącznie zębów, należy pamiętać o leczeniu całej twarzy jako jednostki. Liczne badania dzieci w wieku przedszkolnym wskazują na ścisłą korelację pomiędzy występowaniem nieprawidłowej funkcji i zaburzeń kompleksu szczękowo-twarzowego a obecnością wad zgryzu. 3,5,6,12,13,17,24,25 Jedną z najczęstszych dysfunkcji jest dysfunkcja języka, związana z nieprawidłowym połykaniem $(50,2 \%)$ oraz oddychanie przez usta $(31,9 \%)$. $^{3}$ Wielu badaczy zauważa ścisłą korelację pomiędzy dysfunkcją języka a występowaniem określonych wad zgryzu. Do najczęstszych należy zgryz otwarty, tyłozgryz i przodozgryz. Natomiast mniejsza jest zależność ze zgryzem głębokim i wadami zębowymi. Najmniejszą zależność zaobserwowano również w zaburzeniach poprzecznych. Potwierdzają to liczne badania polskich i zagranicznych autorów. ${ }^{3-6,8-11,13,14}$ Naprzeciw tym 
both Polish and foreign researchers. ${ }^{3-5,6,811,13,14}$ Opponents of these allegations are those who believe that abnormal function of the tongue is a direct result of adapting to the already existing occlusion defects and is the result of adaptation to the surrounding environment. Research by Tulley and Proffit 10,16 indicates that the frontal open bite with protrusion of the upper incisors may hamper keeping the bite and digestive fluids in the mouth. Placing the tongue between the spaced front teeth creates a front seal, which means that pressing the tongue in the presence of anterior open bite can be understood as a physiological adaptation to an existing defect, and not the cause of its formation. The second most common dysfunction is a dysfunction of breathing, or breathing through the mouth. The effect of breathing on the chewing mechanism begins from the very first breath of the newborn. The correct physiological breathing through the nose has a positive effect on the development of the maxillofacial complex. ${ }^{17-19,21,23,26,29,30,33}$ There are two types of mouth breathing dysfunction. For $70 \%$ of people it is habitual breathing, and for $20 \%$ this pattern of breathing is due to reduced air flow through the nose. ${ }^{17}$ Etiological factors of mouth breathing include: upper respiratory tract infections, allergies, hypertrophy of the tonsils, anatomical abnormalities (deviated septum, turbinate hypertrophy), foreign bodies and trauma. ${ }^{26,31}$ If the paediatrician does not find any of the abovementioned causes, and the child continues to breathe constantly through the mouth, it is habitual breathing. Breathing through the mouth correlates with the occurrence of swallowing dysfunction, or tongue thrusting during swallowing. The clinical trial conducted in 2012 by Eyszczarz et al. ${ }^{17}$ on a group of 110 children from Cracow's primary schools, showed that for $70 \%$ of children breathing through the mouth, this kind of breathing was habitual in nature. If an oral breathing circuit persists for a long time, it influences adversely the development of part of craniofacial region and leads to irreversible changes in the activity and construction of this region..$^{29-31}$ Consequences of pathological breathing through the mouth are wide-ranging, affecting not only the masticatory twierdzeniom stoją ci, którzy uważają, że nieprawidłowa funkcja języka wynika bezpośrednio $\mathrm{z}$ dostosowania się do istniejącej już wady zgryzu $i$ jest efektem adaptacyjnym do otaczającego środowiska. Badania Tulley i Proffita ${ }^{10,16}$ podają, że zgryz otwarty przedni z protruzją zębów siecznych górnych może utrudniać utrzymanie kęsa pokarmowego i płynów w jamie ustnej. Umieszczenie języka pomiędzy oddalonymi zębami przednimi, umożliwia uzyskać uszczelnienie przednie, co oznacza, że tłoczenie języka w obecności zgryzu otwartego przedniego może być rozumiane jako fizjologiczna adaptacja do istniejącej wady, a nie przyczyna jej powstawania. Druga co do częstości występowania dysfunkcja to dysfunkcja oddychania, czyli oddychanie przez usta. Wpływ oddychania na narząd żucia rozpoczyna się już od pierwszego oddechu noworodka. Prawidłowe, fizjologiczne oddychanie przez nos wpływa dodatnio na rozwój kompleksu szczękowo-twarzowego. ${ }^{17-19,21,23,26,29,30,33}$ Rozróżnia się dwa rodzaje dysfunkcji oddychania przez usta. W $70 \%$ jest to oddychanie nawykowe, a tylko w $20 \%$ jest to oddychanie spowodowane ograniczoną możliwością przepływu powietrza przez nos. ${ }^{17}$ Czynniki etiologiczne oddychania przez usta to: infekcje górnych dróg oddechowych, alergie, hipertrofia migdałków, nieprawidłowości anatomiczne (krzywa przegroda, przerost małżowin nosowych), ciała obce i urazy. ${ }^{26,31}$ Jeśli lekarz pediatra nie stwierdzi jakiejkolwiek z powyższych przyczyn, a dziecko stale oddycha przez usta, to oddychanie ma charakter nawykowy. Oddychanie przez usta koreluje z występowaniem dysfunkcji połykania, czyli z tłoczeniem języka w trakcie czynności połykania. Badanie kliniczne przeprowadzone 2012 roku przez Łyszczarz i wsp. ${ }^{17}$ na grupie 110 dzieci z krakowskich szkół podstawowych wykazało, że u 70\% dzieci oddychających przez usta, oddychanie to miało charakter nawykowy. Jeżeli ustny tor oddychania utrzymuje się przez długi okres, wpływa niekorzystnie na rozwój części twarzowej czaszki i prowadzi do nieodwracalnych zmian w czynności i budowie tego regionu. ${ }^{29-31}$ Konsekwencje patologicznego oddychania przez usta są bardzo rozległe, obejmujące nie tylko narząd żucia, ale również działają upośledzająco na 
system, but also wrong development of the chest, respiratory and cardiovascular organs. In recent years, the problem of intensified rapid breathing has been on the increase, and it is especially related to the growing number of children with allergies. Having taken this into consideration, it is very important to prevent these consequences.

One of the ways of offering such help is reeducation. Re-education should be widely used in orthopaedic and orthodontic treatment of dysfunction of breathing, swallowing and speech, as it prevents relapse of malocclusion after treatment with relevant appliance is completed. In primary dentition it is a preventive treatment, in mixed dentition it is controlled eruption of the teeth, and in permanent dentition it is the correction of the position of the teeth. In the re-education it is very important to make the little patient aware of the appropriate treatment, and to motivate him or her. Both the patient's and carer's cooperation is crucial here. Carers' negative attitude to "no appliance" treatment is one of the contraindications to its undertaking. Re-education is to make the patient aware of the abnormal reflexes and habits, followed by long-term and systematic training, which would introduce new reflexes, new habits into patients' sub-consciousness. This method affects motion organ through the nervous system and has common elements with myotherapy, the difference being that myotherapy changes tension and muscle strength, and re-education restores proper function of muscles without changing their strength. Indications for re-education are: an infant survived type of swallowing, breathing through the mouth, lazy chewing, incorrect pronunciation. Re-education may be used as the sole method of treatment or as a supporting treatment of malocclusion. Before initiating re-education, it is important to balance the antagonistic muscles through appropriate muscle exercises. ${ }^{1}$

\section{Aim of the study}

The aim of the study was to analyze changes in breathing, swallowing and tongue position during treatment with standard functional elastic appliance with appropriate muscle exercises in children before peak of growth spurt for a period rozwój klatki piersiowej, narządu krążenia i oddychania. W ostatnich latach problem oddychania gwałtownie się potęguje, a związane jest to szczególnie ze wzrastająca liczbą dzieci z alergiami. Biorąc pod uwagę ten fakt, bardzo ważne jest zapobieganie tym konsekwencjom.

Jednym ze sposobów niesienia pomocy jest reedukacja. Reedukacja powinna być powszechnie stosowana w leczeniu ortopedyczno-ortodontycznym w przypadku dysfunkcji oddychania, połykania i wymowy, ponieważ zapobiega nawrotom wady zgryzu po leczeniu właściwymi aparatami. W uzębieniu mlecznym jest to leczenie prewencyjne, w uzębieniu mieszanym sterowane wyrzynanie zębów, a w uzębieniu stałym korekta położenia zębów. W reedukacji bardzo ważne jest uświadomienie małego pacjenta o konieczności leczenia i odpowiednie go zmotywowanie. Bardzo istotna jest zarówno współpraca pacjenta, jak i rodziców. Negatywny stosunek rodziców do leczenia „bez aparatu” jest jednym z przeciwwskazań do podjęcia tej metody leczenia. Reedukacja polega na uświadomieniu nieprawidłowych odruchów i nawyków, a następnie przez długotrwałe i systematyczne ćwiczenia wprowadza nowe odruchy, nowe nawyki do podświadomości. Metoda ta działa na narząd ruchu przez układ nerwowy i ma elementy wspólne z mioterapią, $\mathrm{z}$ różnicą taką, że mioterapia zmienia napięcie i siłę mięśni, a reedukacja przywraca prawidłową czynność mięśni bez zmiany ich siły. Wskazania do reedukacji to: przetrwały niemowlęcy typ połykania, oddychanie przez usta, leniwe żucie, nieprawidłowa wymowa. Reedukacja może być stosowana jako wyłączna metoda leczenia lub jako wspomagająca leczenie wad zgryzu aparatem ortodontycznym. Istotne jest przed reedukacją wyrównania bilansu mięśni działających antagonistycznie za pomocą odpowiednich ćwiczeń mięśniowych. ${ }^{1}$

\section{Cel pracy}

Celem badania była analiza zmian zachodzących w czynności oddychania, połykania oraz pozycji języka podczas leczenia standardowym aparatem czynnościowym elastycznym wraz z odpowiednimi ćwiczeniami mięśniowymi w grupie dzieci przed skokiem wzrostowym, przez okres 
of one year. In addition, changes in occlusion in the sagittal, transverse and horizontal planes and the quality of patients' life during treatment with Trainers were subject to observations. Absence of documented or accurate literature on the use of Trainer-type elastic appliances was the main reason why thorough research on this subject was conducted.

\section{Material and methods}

Clinical trials were conducted in a group of ten patients aged 6 to 10 years. Inclusion criteria for the study group were patients of either sex with milk or mixed dentition before peak of growth spurt (which was assessed on the basis of maturity of cervical vertebrae) with the presence of at least one of the impaired functions of breathing, swallowing, and/or an abnormal position of the tongue during swallowing and with identified partial front open bite (overbite minimum of -2 $\mathrm{mm}$ ) or Class II/1 malocclusion.

The criteria for exclusion from the study group included patients with normal occlusion, or patients after orthodontic treatment with other appliances or patients diagnosed with mechanical obstruction of the upper respiratory tract, or those with permanent teeth. The research was conducted in the years 2014-2015 and received a positive opinion of the Bioethics Committee of the Jagiellonian University (No: KBET/137/B/2013).

Before the study each patient underwent standard diagnostic procedures applicable in the Department of Orthodontics, Dental University Clinic in Cracow, where all clinical procedures were carried out.. These procedures included: gathering the general medical and dental information, examination by an orthodontist, ordering and evaluation of additional examinations: panoramic X-rays, cephalometric radiograph, extra- and intraoral photographs and performance and analysis of plaster diagnostic models. After a thorough analysis of the information obtained, malocclusion was identified and treatment plan developed, which took into account the Trainertype standard elastic appliance and selection of muscle exercises appropriate to the diagnosed type of dysfunction.
1 roku. Dodatkowo obserwacji zostały poddane zmiany zachodzące w okluzji w płaszczyźnie strzałkowej, poprzecznej oraz horyzontalnej oraz jakość życia pacjentów w trakcie leczenia Trainerami. Brak udokumentowanych i ścisłych informacji w literaturze na temat zastosowania aparatów elastycznych typu Trainer skłoniło do przeprowadzenia dokładnych badań na ten temat.

\section{Materiał i metoda}

Badania kliniczne zostały przeprowadzone w grupie 10 pacjentów w wieku od 6 do 10 lat. Kryteria włączenia do grupy badawczej to pacjenci obojga płci, z uzębieniem mlecznym lub mieszanym, przed skokiem wzrostowym (co oceniano na podstawie dojrzałości kręgów szyjnych), z występowanie przynajmniej jednej zaburzonej funkcji spośród funkcji oddychania, połykania i/lub nieprawidłowej pozycji języka w czasie połykania oraz ze stwierdzonym zgryzem otwartym częściowym przednim (szpara niedogryzowa minimum $2 \mathrm{~mm}$ ) lub wadą klasy II/1. Kryterium wykluczenia z grupy badawczej to pacjenci z prawidłową okluzją, pacjenci po leczeniu ortodontycznym innymi aparatami, pacjenci ze zdiagnozowanymi przeszkodami mechanicznymi $\mathrm{w}$ górnych drogach oddechowych, pacjenci $\mathrm{z}$ uzębieniem stałym. Badania były przeprowadzone $\mathrm{w}$ latach 2014-2015 i uzyskały pozytywną opinię Komisji Bioetycznej Collegium Medicum Uniwersytetu Jagiellońskiego (nr: KBET/137/B/2013).

U każdego pacjenta przed przystąpieniem do badania przeprowadzone zostało standardowe, obowiązujące w naszej jednostce, postępowanie diagnostyczne uwzględniające zebranie wywiadu ogólnomedycznego i stomatologicznego, badanie specjalistyczne wykonywane przez lekarza ortodontę, wykonanie i ocena badań dodatkowych: zdjęcie ortopantomograficzne, zdjęcie cefalometryczne, zdjęcia zewnątrz- i wewnątrzustne oraz wykonanie i ocena gipsowych modeli diagnostycznych. Po dokładnej analizie uzyskanych informacji postawiono rozpoznanie dotyczące wady okluzji oraz opracowano plan leczenia z uwzględnieniem rodzaju zastosowanego standardowego, elastycznego aparatu typu Trainer oraz dobór odpowiednich ćwiczeń mięśniowych do rodzaju wy- 
The treatment consisted of the use of elastic functional appliance series EF Evolution of Orthoplus to re-educate the disturbed functions of swallowing and/or breathing. The selection of appliance depended on the age of the patient, namely in the ages between 4 and 8 years EF Start Evolution appliance was used, and between 8 and 11 years of age the EF Trainer Evolution appliance was chosen. In addition, the patient was asked to perform muscle exercises depending on the type of dysfunction occurring. The patients were asked to perform exercises twice a day for about 10 minutes, under the supervision of an adult. In the case of breathing through the mouth the patient was instructed to: 1) breathe deeply through the nose with the mouth closed, the patient is set to "attention" mode, 2) breathe air through the nose with holding/closing one nostril, then exhale with closing/holding the second nostril, and 3) breathe with closed lips and the appliance in place. In the case of persistent infantile type of swallowing it was recommended to: 1) clap the tongue, 2) exercise correct swallowing in front of the mirror, 3) swallow with the appliance on and swallow with the elastics on the tip of the tongue (a child was instructed to swallow while sustaining the elastics in the region of the lingual surface of the maxillary alveolar process). In the case of orbicular oris hypotonia the patient was asked to: 1) drink through a straw, 2) maintain a thin object, e.g.: toothpick between contacting lips with the mouth forming a spout shape and 3) whistle.

Diagnostic models were made before the treatment with Trainer-type functional elastic appliance started and at the end of treatment (after 12 months). The following parameters were measured and compared on the models: overjet and overbite, intermolar width (measured according to McNamara ${ }^{36}$ ) and intercanine width. Intra- and extraoral photographs were taken before orthodontic treatment, after 6 months from the beginning of treatment and after treatment with Trainer-type functional elastic appliance was completed. Cephalometric radiographs were described by means of cephalometric Kracovia Composite Analysis, which in turn is based on the Bjorka analysis. ${ }^{20}$ stępującej dysfunkcji. Leczenie polegało na zastosowaniu aparatu czynnościowego elastycznego z serii EF Evolution firmy Orthoplus w celu reedukacji zaburzonych funkcji połykania lub/i oddychania. Dobór aparatu uzależniano od wieku pacjenta, w przedziale wiekowym od 4 do 8 roku życia stosowano aparat EF Start Evolution, a od 8 do 11 roku życia aparat EF Trainer Evolution. Dodatkowo zalecone było wykonywanie ćwiczeń mięśniowych w zależności od rodzaju występującej dysfunkcji. Zalecane było wykonywanie ćwiczeń dwa razy dziennie przez około 10 minut, po nadzorem dorosłej osoby. W przypadku oddychania przez usta zalecano: 1) oddychanie głęboko przez nos, z zamkniętymi ustami, pacjent ustawiony na „baczność”, 2) nabranie powietrza przez nos z zatkaniem jednego otworu nosa, po czym wydech z zatkaniem drugiego otworu nosa i 3) oddychanie ze złączonymi wargami i założonym aparatem. W przypadku przetrwałego niemowlęcego typu połykania zalecano: 1) klaskanie językiem, 2) ćwiczenia prawidłowego sposobu połykania przed lustrem, 3) połykanie z założonym aparatem oraz połykanie z wyciągiem elastycznym na czubku języka (zalecano dziecku połykanie $\mathrm{z}$ utrzymywaniem wyciągu w rejonie językowej powierzchni wyrostka zębodołowego szczęki. W przypadku hipotonii mięśnia okrężnego ust zalecano: 1) picie przez słomkę, 2) utrzymywanie cienkiego przedmiotu, np. wykałaczki między złączonymi w dziubek ustami oraz 3) gwizdanie. Wszystkie procedury kliniczne zostały przeprowadzone w Poradni Ortodoncji Uniwersyteckiej Kliniki Stomatologicznej w Krakowie.

Modele diagnostyczne były wykonywane przed rozpoczęciem leczenia aparatem czynnościowym elastycznym typu Trainer oraz na końcu leczenia (po okresie 12 miesięcy). Na modelach mierzono i porównano następujące parametry: nagryz poziomy i pionowy, szerokość międzytrzonowcowa (mierzona według McNamary) ${ }^{36}$ oraz szerokość międzykłowa. Zdjęcia cyfrowe wewnątrz- i zewnątrzustne wykonywano przed rozpoczęciem leczenia ortodontycznego, po 6 miesiącach od momentu rozpoczęcia leczenia oraz po zakończonym leczeniu aparatem czynnościowym elastycznym typu Trainer. Zdjęcia cefalometryczne opisywa- 
The above-mentioned radiographic examination was performed on each patient before and after treatment with Trainer-type elastic appliance. The following parameters were compared before and after treatment: evaluated maxillary sagittal (SNA) and mandible (SNB) relationship to the cranial base, sagittal jaw relationship (ANB), vertical jaw relationships (NL/ML) and the morphology of the mandible. From the dental parameters the upper (Ils/NL) and lower (Ili/ML) incisor inclination to the bone basics and the value of the inter-incisal angle was compared.

The evaluation of tongue activity when swallowing was performed during each visit in the following manner: the patient was sitting in the dental chair and was asked to swallow. The position of the tongue during swallowing (lips open) was evaluated. During swallowing, the tongue should rest on the lingual ridge of the maxillary alveolar process. If the tongue during swallowing is located between the dental arches it indicates the existence of a "tongue thrust" associated with persistent type of baby swallowing. In addition, at the beginning and end of the treatment, a palatogram was carried out in order to assess tongue dysfunction during swallowing. ${ }^{2}$ As required by this technique, using a spatula the tongue was covered with a thin layer of high accuracy impression material of (Bisico Suhy S4). The patient was instructed to swallow a small amount of water, and immediately after this a photograph of the palate (with the use of a mirror) was taken. The palatogram was assessed directly on the palate photograph, dividing it into sectors and marking sectors where the tongue was placed during swallowing. Three sectors (areas) where the tongue contacted the palate were marked on the palatogram. The first sector was the sector (I) where the tongue was in contact mainly with the upper incisors, and was pressed between the teeth of the upper and lower incisors. The second sector (II) was the sector which the tongue touched distally behind the line joining mesial canine surfaces, the third sector (III) behind the line joining mesial surfaces of the first milk molar teeth or behind the line joining mesial surfaces of the first premolar teeth.

Assessment of the breathing pattern (breathing no za pomocą analizy cefalometrycznej Kracovia Composite Analysis opierającej się na analizie Bjorka. ${ }^{20}$

Wymienione badania obrazowe wykonywano u każdego pacjenta przed rozpoczęciem leczenia aparatem elastycznym Trainer oraz po zakończonym leczeniu. Porównano przed i po leczeniu następujące parametry: oceniano relację strzałkową szczęki (SNA) i żuchwy (SNB) do podstawy czaszki, szczęki do żuchwy (ANB), relacje pionowe podstaw kostnych(NL/ML) oraz morfologię żuchwy. Z parametrów zębowych porównano kąt górnego (Ils/NL) i dolnego (Ili/ML) siekacza do podstaw kostnych oraz wartość kąta międzysiecznego.

Ocenę czynności języka w trakcie połykania wykonywano w trakcie każdej wizyty kontrolnej w następujący sposób: siedzącemu na fotelu dentystycznym pacjentowi zaleca się przełknąc ślinę. Ocenia się położenie języka w trakcie połykania (wargi rozwarte). Prawidłowo język w trakcie połykania powinien opierać się o językowy stok wyrostka zębodołowego szczęki. Jeśli język w trakcie czynności połykania znajduje się pomiędzy łukami zębowymi, wskazuje to na występowanie „tłoczenia języka” związanego z przetrwałym niemowlęcym typem połykania. Ponadto na początku i na końcu leczenia wykonywano palatogram oceniający metodą palatografii bezpośredniej dysfunkcję języka $\mathrm{w}$ trakcie połykania. ${ }^{2}$ Zgodnie z wymogami tej techniki język pokrywano za pomocą szpatułki cienką warstwą masy wyciskowej o wysokiej dokładności Bisico S4 Suhy. Zastosowanym ćwiczeniem czynnościowym było przełknięcia niewielkiej ilości wody, po którym natychmiast wykonywane było, z zastosowaniem lusterka, zdjęcie podniebienia. Palatogram oceniano bezpośrednio na zdjęciu podniebienia, dzieląc go na sektory i oznaczając sektory, w których znalazł się język podczas przełknięcia. Na palatogramie wyznaczono trzy sektory (obszary) kontaktu języka z podniebieniem. Pierwszy (I), gdzie język kontaktował się głównie z zębami siecznymi górnymi i był tłoczony pomiędzy zęby sieczne górne i dolne. Drugi sektor (II), gdzie język kontaktował się dystalnie za linią łączącą mezjalne powierzchnie kłów, trzeci sektor (III) za linią łączącą mezjal- 
through the nose-correct, breathing through the mouth-habitual or obstructive, mixed breathing) was based on the observation of the child at rest (sitting in the dentist's chair) and with exerting a little effort (walking short distance when heading towards the dentist's chair) and on nasal flows assessment was performed by means of a simple test: a patient was asked to put a piece of paper between the lips and to breathe through the nose. It was monitored whether the patient breathed freely through the nose or whether it caused difficulties. ${ }^{2}$ It was necessary to interview a parent/ carer on the state of child's health and to request that the child's breathing activity be monitored during the day when doing homework, playing, watching TV, etc., and during sleep. At this stage also systemic diseases should be excluded: those accompanying rhinitis (allergies, strep throat, sinusitis, ear infections, bronchitis), anatomical dysfunctions such as deviated septum of the nose, nasal polyps, enlarged tonsils. In the case of any doubt, a consultation with the ENT specialist was recommended. The control of breathing was based on measuring the time during which the patient was able to breathe through the nose (the patient was unaware of the purpose of the study), which was determined by joined lips. The survey was carried out as follows: the relaxed patient sat in the chair. He was asked to breathe through the nose. Using a stopwatch time was measured until the patient opened the mouth during breathing activity.

Orbicularis oris tension was measured with an electronic dynamometer (unit of measurement in kilograms). As the mouthpiece, a standard vestibular plate (medium size) was used. The patient was in a sitting position (on the edge of a chair), sitting straight. He was asked to hold the mouthpiece using his orbicularis oris muscles and pull strongly up to the moment of its falling out. This way maximal orbicularis oris muscle tension measurement was obtained. This activity was repeated three times with short intervals between measurements.

The patients attended for control visits at regular intervals. During the first visit (visit 0 ), terms of use of a given appliance were discussed, ne powierzchnie zębów pierwszych mlecznych trzonowców lub za linią łączącą mezjalne powierzchnie pierwszych zębów przedtrzonowych.

Ocena sposobu oddychania (oddychanie przez nos - prawidłowe, oddychanie przez usta - nawykowe czy obstrukcyjne, oddychanie mieszane) opierała się na obserwacji dziecka podczas spoczynku (siedzącego na fotelu dentystycznym) i przy niewielkim wysiłku (pokonującego niewielki dystans zmierzając na fotel dentystyczny) i ocenie przepływów nosowych przy użyciu prostego testu: zalecano wziąć kartkę papieru pomiędzy złączone wargi i oddychać nosem. Obserwacja pozwalała stwierdzić, czy pacjent ma swobodny przepływ przez nos, czy sprawia mu to dużą trudność. ${ }^{2}$ Należało zebrać wywiad z rodzicem/ opiekunem na temat stanu zdrowia dziecka i zalecić obserwację czynności oddychania prowadzoną przez rodzica $\mathrm{w}$ dzień podczas odrabiania lekcji, zabawy, oglądania telewizji itp. oraz podczas snu dziecka. Należy wykluczyć choroby ogólnoustrojowe: przebiegające z nieżytem nosa (alergie, anginy, choroby zatok, zapalenia ucha, zapalenia oskrzeli), zaburzenia anatomiczne typu krzywa przegroda nosa, obecność polipów nosa, powiększone migdałki. W razie wątpliwości zalecana była konsultacja specjalistyczna $\mathrm{z}$ laryngologiem. Kontrola sposobu oddychania polegała na pomiarze czasu, podczas którego pacjent nieświadomy celu badania, jest w stanie oddychać przez nos, czego wyznacznikiem są złączone usta. Badanie przeprowadzone było w następujący sposób: pacjent powinien siedzieć zrelaksowany na fotelu. Zaleca się, aby oddychał przez nos. Mierzymy czas stoperem do momentu, kiedy otworzy usta w czasie czynności oddychania.

Napięcie mięśnia okrężnego ust mierzono za pomocą dynamometru elektronicznego (jednostka pomiarowa w kilogramach). Jako ustnik zastosowano standardową płytkę przedsionkową w średnim rozmiarze. Badany pacjent $\mathrm{w}$ pozycji siedzącej (na krawędzi krzesła), był wyprostowany i oddalony od oparcia. Pacjent utrzymywał ustnik mięśniem okrężnym ust i miał zalecenie mocnego ciągnięcia ustnika aż do momentu wypadnięcia. Wtedy uzyskiwano maksymalny pomiar napięcia mięśnia okrężnego ust. Czynność tę powtarzano 
measurements and palatogram were taken. Each patient presented for five control visits: the first visit after 1,5 months, the second after 3 months, the third after 6 months, the fourth after 9 months and the last, the fifth one, after 12 months. During the third visit (6 months after fitting the appliance) photographic documentation and measurements were taken again. After 12 months, a complete photographic documentation along with final radiography was performed, final models and all the measurements were taken.

When the results were assessed, the comparison of the following was carried out: diagnostic models, extra-oral and intra-oral photographs, cephalometric analysis (before and after treatment), the activity of the tongue during swallowing (clinical test and palatogram), breathing activity (time measurement, clinical examination and an interview with a parent/carer was carried out), orbicular oris tension (measurement before and after treatment was compared), and an assessment of the quality of patient's life during treatment with Trainer-type functional elastic standard appliance was carried out.

\section{Results}

The main aim of this study was to investigate changes in the activity of breathing, swallowing and tongue position during treatment with functional elastic appliance combined with appropriate muscle exercises in children before peak of growth spurt for a period of one year. In addition, changes in an occlusion in the sagittal, transverse and vertical plane and changes in the quality of patient's life during treatment with Trainers were observed (Table 1).

Significant changes among all patients in the activity of swallowing were noted. Normally, the tongue should contact the lingual ridge of the maxillary alveolar process, back from the upper incisors. Palatogram for each patient was taken before and after treatment. During each control visit, the position of the tongue during swallowing was checked. It was noted that improvement in the position of the tongue occurred after the shortest time of 3 months. For the patients with open bite dysfuntion this time was significantly longer, it trzy razy z krótkimi przerwami pomiędzy pomiarami.

Pacjenci byli kontrolowani w regularnych odstępach czasu. Pierwsza wizyta (wizyta 0), na której omawiano zasady użytkowania oddawanego aparatu oraz wykonywano pomiary i palatogram. U każdego pacjenta przeprowadzono pięć wizyt kontrolnych: pierwsza po 1,5 miesiącu, druga po 3 miesiącach, trzecia po 6 miesiącach, czwarta po 9 miesiącach i ostatnia, piąta po 12 miesiącach. $\mathrm{Na}$ wizycie trzeciej (po 6 miesiącach od oddania aparatu) ponownie wykonywano dokumentację fotograficzną oraz pomiary. Po 12 miesiącach wykonywano pełną dokumentację fotograficzną wraz $\mathrm{z}$ badaniami obrazowymi, modele końcowe oraz wszystkie pomiary.

Oceniając wyniki przeprowadzano porównanie: modeli diagnostycznych, zdjęć zewnątrz- i wewnątrzustnych, analiz cefalometrycznych (przed leczeniem i po leczeniu), czynność języka w trakcie połykania (badanie kliniczne oraz palatogram), czynności oddychania (wykonywano pomiar czasu, przeprowadzano badanie kliniczne oraz wywiad z opiekunem), napięcia mięśnia okrężnego ust (porównywano pomiar przed leczeniem i po leczeniu) oraz przeprowadzano ocenę jakości życia pacjentów podczas leczenia aparatem standardowym elastycznym typu Trainer.

\section{Wyniki}

Głównym celem pracy było zbadanie zmian zachodzących w czynności oddychania, połykania oraz pozycji języka podczas leczenia aparatem czynnościowym elastycznym wraz z odpowiednimi ćwiczeniami mięśniowymi $\mathrm{w}$ grupie dzieci przed skokiem wzrostowym, przez okres 1 roku. Dodatkowo obserwacji zostały poddane zmiany zachodzące w okluzji w płaszczyźnie strzałkowej, poprzecznej oraz horyzontalnej oraz jakość życia pacjentów w trakcie leczenia Trainerami (Tab. 1).

U wszystkich pacjentów zauważono znaczące zmiany w poprawie czynności połykania. Prawidłowo język powinien kontaktować się z językowym stokiem wyrostka zębodołowego szczęki, dotylnie od zębów siecznych górnych. U każdego pacjenta został wykonany palatogram przed leczeniem oraz po zakończeniu leczenia. Na każ- 
Table 1. The characteristics of patients participating in the study

\begin{tabular}{|c|c|c|c|c|c|c|c|}
\hline Number & Sex & Age & $\begin{array}{c}\text { Type } \\
\text { of malocclusion }\end{array}$ & Breathing type & $\begin{array}{l}\text { Tongue } \\
\text { thrusting }\end{array}$ & $\begin{array}{l}\text { Orbicular oris } \\
\text { hypotonia }\end{array}$ & $\begin{array}{l}\text { Lips } \\
\text { competency }\end{array}$ \\
\hline 1. & $\mathrm{~F}$ & $8 y 7 m$ & $\|(i)$ & $\begin{array}{l}\text { Mixed (with predominance } \\
\text { of oral type) }\end{array}$ & Yes & Yes & $\begin{array}{l}\text { Potentially } \\
\text { competent }\end{array}$ \\
\hline 2. & $\mathrm{~F}$ & $6 y 7 m$ & OpB Ant & Oral breathing & Yes & Yes & Incompetent \\
\hline 3. & $\mathrm{~F}$ & $8 y 5 m$ & OpB Ant & Oral breathing & Yes & Yes & Incompetent \\
\hline 4. & $\mathrm{~F}$ & $6 y 10 \mathrm{~m}$ & OpB Ant & Oral breathing & Yes & Yes & Incompetent \\
\hline 5. & $M$ & $8 y 6 m$ & OpB Ant & $\begin{array}{l}\text { Mixed (with predominance } \\
\text { of oral type) }\end{array}$ & Yes & Yes & $\begin{array}{l}\text { Potentially } \\
\text { competent }\end{array}$ \\
\hline 6. & $F$ & $7 y 8 m$ & OpB Ant & $\begin{array}{l}\text { Mixed (with predominance } \\
\text { of oral type) }\end{array}$ & Yes & Yes & Incompetent \\
\hline 7. & $M$ & $8 y 3 m$ & $\|(\mathrm{i})$ & Mixed & Yes & Yes & $\begin{array}{l}\text { Potentially } \\
\text { competent }\end{array}$ \\
\hline 8. & $\mathrm{~F}$ & 6y $3 m$ & II (with lip trap) & Oral breathing & Yes & Yes & Incompetent \\
\hline 9. & $\mathrm{~F}$ & $9 y 2 m$ & II (with lip trap) & Oral breathing & Yes & Yes & Incompetent \\
\hline 10. & $M$ & $7 y 9 m$ & OpB Ant & Oral breathing & Yes & Yes & Incompetent \\
\hline
\end{tabular}

OpB Ant - open bite anterior.

Table 2. The changes in tongue position during twelve months of treatment

\begin{tabular}{ccccc} 
Number & $\begin{array}{c}\text { Tongue } \\
\text { thrusting } \\
\left(\text { ( }^{\text {st }} \text { control }\right. \\
\text { visit) }\end{array}$ & $\begin{array}{c}\text { After 3-6 } \\
\text { moths }\end{array}$ & $\begin{array}{c}\text { After 9 } \\
\text { months }\end{array}$ & $\begin{array}{c}\text { After 12 } \\
\text { months }\end{array}$ \\
1. & Yes & Yes & No & No \\
\hline 2. & Yes & Yes & Yes & Yes \\
\hline 3. & Yes & Yes & Yes & No \\
\hline 4. & Yes & No & No & No \\
\hline 5. & Yes & Yes & No & No \\
\hline 6. & Yes & No & No & No \\
\hline 7. & Yes & Yes & Yes & No \\
\hline 8. & Yes & No & No & No \\
\hline 9. & Yes & Yes & Yes & No \\
\hline 10. & Yes & Yes & Yes & Yes \\
\hline
\end{tabular}

dej wizycie kontrolnej była sprawdzana pozycja języka podczas czynności połykania. Zauważono, że poprawa pozycji języka w trakcie czynności połykania następowała po najkrótszym czasie 3 miesięcy. U pacjentów ze zgryzem otwartym czas ten był wyraźnie dłuższy, było to około 6-9 miesięcy terapii (Tab. 2). U dwóch pacjentów ze zgryzem otwartym tłoczenia nie udało się całkowicie wyeliminować. Po zakończonej reedukacji u wszystkich dzieci z wadą klasy II/1, język w czasie połykania prawidłowo kontaktował się na językowym stoku wyrostka zębodołowego szczęki. Właściwą strefę określono jako sektor II lub III (Fig. 1 - palatogram). Zauważono również znaczną poprawę w funkcji mięśnia okrężnego ust w trakcie połykania, tzn. wraz z prawidłową pozycją języka w czasie połykania, uzyskano mniejszy udział w połykaniu mięśnia okrężnego ust (zmniejszyła się jego nadaktywność w czasie połykania). 


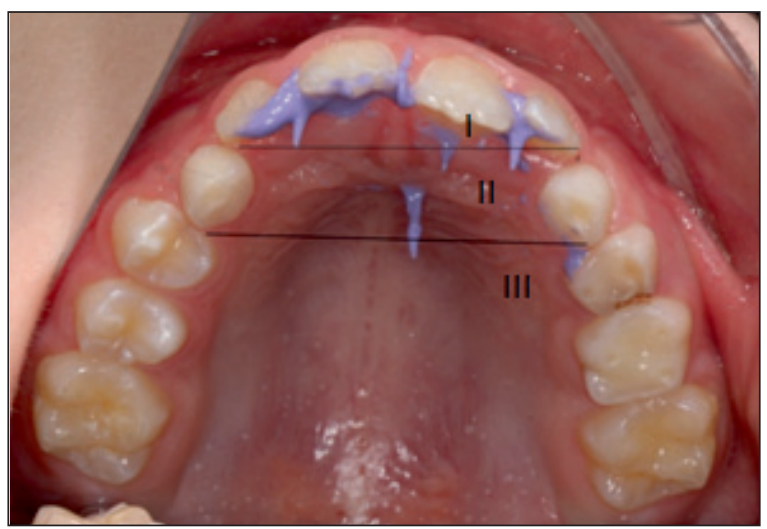

Fig.l. Palatogram

took about 6-9 months of therapy (Table 2). For two patients with open bite the tongue thrusting activity could not be entirely eliminated. After reeducation was completed all children with Class II/ 1 , the tongue (during swallowing) could touch the lingual ridge of the maxillary alveolar process. The right zone was determined as sector II or III (Fig. 1 - palatogram). Significant improvement in orbicular oris function during swallowing was observed, i.e. with the correct position of the tongue during swallowing, a smaller involvement of orbicular oris in swallowing was obtained (its hyperactivity during swallowing decreased).

\section{Changes in respiratory function and competence of the lips}

In the study group, $40 \%$ was of the mixed breathing (oronasal track of breathing) with oral predominance, especially among children with moderate Class II malocclusion. $60 \%$ of the children showed full oral type of breathing: the children with a large Class II and the open bite. All the children who presented habitual mouth breathing suffered from incompetent lips and the habit of tongue thrust. The degree of improvement of the respiratory function was determined by the time during which the child could breathe with closed lips. The minimum of 10 minutes was set, which meant a significant positive change in the way of breathing mainly from oral to nasal. After the treatment was completed all the patients reported improvement in competence of lips. In

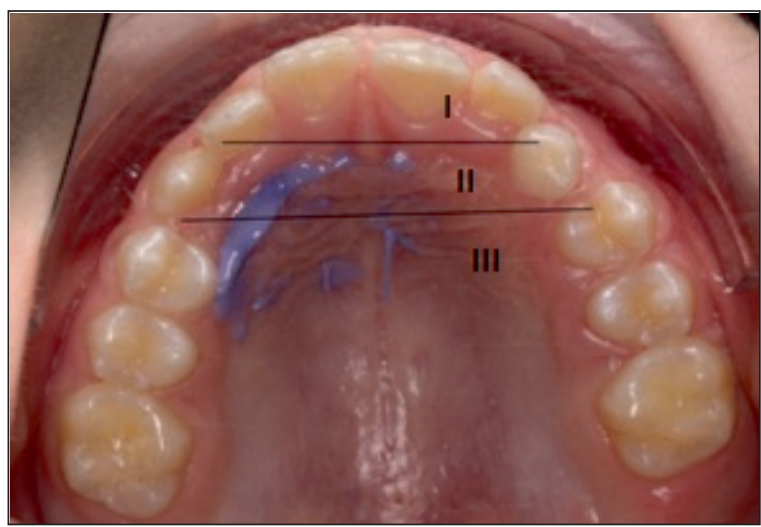

\section{Zmiany zachodzące w czynności oddycha- nia i kompetencja warg}

W grupie badanych 40\% wykazywało mieszane oddychanie (tor oddychania ustno-nosowy) z przewagą ustnego, szczególnie u dzieci z umiarkowaną wadą klasy drugiej. U 60\% dzieci wykazywało całkowity ustny tor oddychania: dzieci z dużą wadą klasy drugiej i ze zgryzem otwartym. Wszystkie dzieci, u których występowało nawykowe oddychanie przez usta wykazywały niekompetentne wargi oraz nawyk tłoczenia języka. Stopień poprawy funkcji oddychania określano poprzez mierzenie czasu, podczas którego dziecko oddychało z zamkniętymi wargami. Ustalono próg czasowy 10 minut, który oznaczał znaczną pozytywną zmianę sposobu oddychania $\mathrm{z}$ ustnego na głównie nosowy. U wszystkich pacjentów po zakończonym leczeniu została poprawiona kompetencja warg. U 70\% leczonych dzieci wargi zostały określone jako super kompetentne, a czas mierzony przekroczył próg 10 min u 90\% badanych (Tab. 3).

Wywiad $\mathrm{z}$ rodzicami potwierdził $\mathrm{u}$ wszystkich pacjentów znaczną poprawę w funkcji oddychania. Rodzice zwrócili uwagę na prawidłową funkcję warg, równowagę $\mathrm{w}$ mięśniach twarzy (zmniejszenie napięcia mięśnia bródkowego) oraz zgłaszali pozytywne zmiany w wyglądzie swoich dzieci, używając sformułowania, że dziecko „wyładniato” oraz „nauczyło się trzymać usta zamknięte". 
Table 3. Characteristics of respiratory function and the function of the lips during treatment

\begin{tabular}{|c|c|c|c|c|}
\hline Number & $\begin{array}{l}\text { Breathing } \\
\text { type }\end{array}$ & $\begin{array}{l}\text { Time (in sec.) after which the patient } \\
\text { started to breathe through the mouth }\end{array}$ & $\begin{array}{l}\text { Time measured after the treatment } \\
\text { was completed ( } 10 \text { min minimum) }\end{array}$ & $\begin{array}{l}\text { Breathing track and lips competence } \\
\text { (after the } 12 \text { months) }\end{array}$ \\
\hline 1. & Mixed & 16.97 & $10 \mathrm{~min}$ & Nasal, lips competent \\
\hline 2. & Oral & 16.00 & 60.02 sek & $\begin{array}{l}\text { Mixed, with predomenence of nasal, } \\
\text { lips potentially competent }\end{array}$ \\
\hline 3. & Oral & 20.42 & $10 \mathrm{~min}$ & Nasal, lips competent \\
\hline 4. & Oral & 5.30 & $10 \min$ & Nasal, lips competent \\
\hline 5. & Mixed & 42.00 & $10 \min$ & Nasal, lips competent \\
\hline 6. & Mixed & 109.00 & $10 \min$ & Mixed, lips potentially competent \\
\hline 7. & Mixed & 120.3 & $10 \mathrm{~min}$ & Nasal, lips competent \\
\hline 8. & Oral & 9.70 & $10 \min$ & Nasal, lips competent \\
\hline 9. & Oral & 21.00 & $10 \min$ & Nasal, lips competent \\
\hline 10. & Oral & 0.32 & $10 \min$ & Nasal, lips potentially competent \\
\hline
\end{tabular}

$70 \%$ of treated children their lips were defined as super competent and the time measured exceeded the threshold of $10 \mathrm{~min}$ in $90 \%$ of treated children (Table 3).

Interviews with parents/carers confirmed significant improvements in respiratory function among all patients. They paid attention to the proper function of the lips, the balance of the facial muscles (reduction of the mental muscle tension), and reported positive changes in the appearance of their children, which was reflected in the expression that the child "got prettier" and "learned to keep the mouth shut".

\section{Orbicular oris tension}

All patients with incompetent lips, oral or mixed breathing pattern, showed low value of orbicular oris tension and suffered from muscle hypotonia at the beginning of treatment.

The tension of orbicular oris increased among all patients after the treatment was completed (Table 4). Improvement in orbicular oris function during swallowing and its balance when closing the lips (no more excessive muscle contraction when trying to close the mouth) was noted among

\section{Napięcie mięśnia okrężnego ust}

Wszyscy pacjenci z niekompetentnymi wargami, oddychaniem ustnym lub mieszanym, wykazali niskie wartości napięcia mięśnia okrężnego ust (NMOU) oraz występowała hipotonia mięśnia na początku leczenia.

U wszystkich dzieci po leczeniu zwiększyło się napięcie mięśnia okrężnego (Tab. 4). U wszystkich dzieci zauważono poprawę w funkcji mięśnia okrężnego ust $\mathrm{w}$ trakcie połykania $\mathrm{i}$ jego równowage przy zamykaniu warg (brak nadmiernego skurczu mięśnia przy próbie zamykania ust). Wzrost napięcia mięśnia okrężnego ust ściśle koreluje z uzyskaniem poprawy funkcji oddychania (przewaga oddychania przez usta) i całkowitą kompetencją warg.

\section{Analiza zdjęć cefalometrycznych}

Brak znacznych różnic dotyczących danych cefalometrycznych opisujących relacje strzałkową szczęki i żuchwy do podstawy czaszki, szczęki do żuchwy, relacje pionowe podstaw kostnych oraz typ wzrostu żuchwy przed leczeniem i po leczeniu aparatem elastycznym.

Relacje zębowe opisane zostały poprzez kąty 
Table 4. Measurement of the orbicularis oris tension

\begin{tabular}{|c|c|c|c|}
\hline Number & Orbicular oris tension - $1^{\text {st }}$ visit $[\mathrm{kg}]$ & Orbicular oris tension - after 6 months & Orbicular oris tension - after 12 months \\
\hline 1. & $\begin{array}{l}0.14 \\
0.23 \\
0.20\end{array}$ & $\begin{array}{l}0.26 \\
0.39 \\
0.30\end{array}$ & $\begin{array}{l}0.71 \\
0.70 \\
0.77\end{array}$ \\
\hline 2. & $\begin{array}{l}0.37 \\
0.44 \\
0.62\end{array}$ & $\begin{array}{l}0.34 \\
0.51 \\
0.53\end{array}$ & $\begin{array}{l}1.73 \\
1.86 \\
1.89\end{array}$ \\
\hline 3. & $\begin{array}{l}0.63 \\
0.34 \\
0.47\end{array}$ & $\begin{array}{l}0.34 \\
0.73 \\
0.64\end{array}$ & $\begin{array}{l}1.99 \\
1.73 \\
1.33\end{array}$ \\
\hline 4. & $\begin{array}{l}0.14 \\
0.26 \\
0.37\end{array}$ & $\begin{array}{l}0.70 \\
0.77 \\
0.72 \\
\end{array}$ & $\begin{array}{l}2.07 \\
2.11 \\
2.34 \\
\end{array}$ \\
\hline 5. & $\begin{array}{l}0.30 \\
0.37 \\
0.80\end{array}$ & $\begin{array}{l}0.49 \\
0.33 \\
0.28\end{array}$ & $\begin{array}{l}1.65 \\
3.04 \\
2.66\end{array}$ \\
\hline 6. & $\begin{array}{l}0.53 \\
0.76 \\
0.23\end{array}$ & $\begin{array}{l}0.27 \\
0.20 \\
0.15\end{array}$ & $\begin{array}{l}2.18 \\
2.06 \\
2.71\end{array}$ \\
\hline 7. & $\begin{array}{l}0.21 \\
0.11 \\
0.23\end{array}$ & $\begin{array}{l}1.37 \\
1.54 \\
2.01 \\
\end{array}$ & $\begin{array}{l}1.78 \\
2.14 \\
1.99 \\
\end{array}$ \\
\hline 8. & $\begin{array}{l}0.41 \\
0.38 \\
0.63\end{array}$ & $\begin{array}{l}1.38 \\
1.11 \\
0.91\end{array}$ & $\begin{array}{l}1.42 \\
0.86 \\
1.23\end{array}$ \\
\hline 9. & $\begin{array}{l}0.32 \\
0.40 \\
0.33\end{array}$ & $\begin{array}{l}0.95 \\
1.41 \\
1.49\end{array}$ & $\begin{array}{l}1.73 \\
1.27 \\
0.91\end{array}$ \\
\hline 10. & $\begin{array}{l}0.69 \\
1.32 \\
1.58\end{array}$ & $\begin{array}{l}1.29 \\
2.03 \\
1.95\end{array}$ & $\begin{array}{l}1.54 \\
1.94 \\
1.65\end{array}$ \\
\hline
\end{tabular}

all patients. The increase in orbicular oris tension correlates with the improvement of respiratory function (dominance of mouth breathing) and complete competence of lips.

\section{Cephalometric radiograph analysis}

No significant differences were observed in the cephalometric data describing the maxillary (SNA) and mandibular (SNB) sagittal relationship to the cranial base, sagittal jaw relationship (ANB),
Ils/NL, Ili/ML oraz kąt międzysieczny. Uzyskano znaczną poprawę kąta Ils/NL, natomiast nieznaczne pogorszenie kąta Ili/ML i wychylenie dolnych zębów siecznych wraz z wyrostkiem zębodołowym.

\section{Analiza modeli diagnostycznych}

U wszystkich pacjentów nastąpiła poprawa wymiaru nagryzu poziomego i pionowego, co koreluje z pomiarami na zdjęciu cefalometrycznym oraz 
vertical jaw relationships (NL/ML) and the type of mandibular growth before and after treatment with functional elastic appliance.

Dental relations were described by angles Ils/ $\mathrm{NL}, \mathrm{Ili} / \mathrm{ML}$ and inter-incisal angle. A significant improvement in the angle Ils / Nl was achieved, but the slight deterioration of Ili/ML angle and the proclination of the lower incisors with the alveolar process was observed as well.

\section{Study models analysis}

Among all the patients, improvement in dimension of overjet and overbite was seen, which correlates with the measurements in the cephalometric analysis, with tongue activity improvement and the improvement of the competence of the lips. Improving the overjet was the result of the retrusion of the upper incisors and a slight protrusion of the lower incisors, which is illustrated by the Ils / NL and Ili / ML angles. All children with improvement in tongue activity during swallowing showed improvement in overbite.

Little or no improvement was noted in overbite dimension and function of the tongue in patients with skeletal open bite, which confirms the principle that in this group of patients tongue thrusting is the act of adaptation to the existing malocclusion and it is necessary to ensure the front seal.

The patient No. 8 with Class II division 1, with "lip trap" and a large overjet row $9 \mathrm{~mm}$, after eliminating the dysfunction of the lower lip, an improvement in overjet to $3 \mathrm{~mm}$ was visible after 6 months.

\section{Discussion}

The tongue plays an important role in many vital activities such as breathing, chewing, swallowing, speeking. Its normal function is extremely important because it affects the development of the entire dentofacial complex. In the study group, all patients suffered from tongue thrusting and lips incompetence. These abnormal activities closely correlate with the wrong type of habitual mouth breathing. The characteristics of patients with these dysfunctions include the following poprawą czynności języka i poprawą kompetencji warg. Poprawa nagryzu poziomego była wynikiem cofnięcia zębów siecznych górnych oraz nieznacznym wychyleniem zębów siecznych dolnych, co obrazują również kąty Ils/NL oraz Ili/ ML. U wszystkich dzieci, u których nastąpiła poprawa czynności języka w trakcie połykania, wykazano poprawę nagryzu pionowego.

Zauważono nieznaczną lub brak poprawy wymiaru nagryzu pionowego oraz czynności języka u pacjentów ze zgryzem otwartym szkieletowym, co potwierdza zasadę, że w tej grupie pacjentów tłoczenie języka jest czynnością adaptacyjną do istniejącej wady $\mathrm{i}$ jest konieczne w celu zapewnienia uszczelnienia przedniego.

U pacjentki $\mathrm{nr} 8 \mathrm{z}$ klasą II podgrupą 1 wraz $\mathrm{z}$,pułapką wargową" oraz dużym nagryzem poziomym rzędu 9mm, po wyeliminowaniu dysfunkcji wargi dolnej już po 6 miesiącach nastąpiła poprawa nagryzu poziomego do $3 \mathrm{~mm}$.

\section{Dyskusja}

Język odgrywa istotną rolę w wielu czynnościach życiowych jak oddychanie, żucie, połykanie, mowa. Jego prawidłowa funkcja jest niezwykle ważna, ponieważ wpływa na rozwój całego kompleksu zębowo-twarzowego. W grupie badanej wszyscy pacjenci wykazywali tłoczenie języka oraz niekompetencję warg. Te nieprawidłowe czynności ściśle korelują z nieprawidłowym nawykowym typem oddychania przez usta. Cechami charakterystycznymi dla pacjentów z powyższymi dysfunkcjami są następujące wady zgryzu: zgryz otwarty lub wada klasy II podgrupa 1, zgryz krzyżowy, stłoczenia w odcinku przednim. Powyższe wady zgryzu powstały jako efekt wtórny nieprawidłowych czynności mięśni otaczających szparę ustną. Zaburzona funkcja oddychania i jej wpływ na rozwój i wzrost struktur twarzoczaszki obrazuje relację ,forma-funkcja”. Oddychanie przez usta nie jest bezpośrednią przyczyną nieprawidłowego wzrostu, lecz zaburza funkcję mięśni, a nieprawidłowo działające mięśnie twarzoczaszki wpływają na nieprawidłowy wzrost i tym sposobem na rozwój wad zgryzu. ${ }^{33}$ Dlatego ważne jest jak najszybsze wyeliminowanie tych nieprawidłowych funkcji mięśni twarzoczaszki i umożliwienie pra- 
malocclusions: open bite or Class II division 1, crossbite, crowding in the anterior segment. This malocclusion has formed as a secondary effect of abnormal muscle activity surrounding the mouth. Impaired respiratory function and its impact on growth and development of craniofacial structures illustrate the "form-function" relationship. Breathing through the mouth is not a direct cause of abnormal growth, but interferes with the function of muscles, and malfunctioning facial muscles affect the abnormal growth, and thus the development of malocclusions. ${ }^{33}$ That is why it is important to eliminate these abnormal facial muscle dysfunctions and to enable the normal development of the dental arches and the entire craniofacial region as soon as possible. In the literature, many authors emphasize the fact that the sooner the correct function returns, the easier and faster, and even spontaneously without therapy with orthodontic appliance, the revocation of malocclusion formed on the background of dysfunction is possible. 1,29,33 It should be pointed out that in the case of impaired muscle function surrounding the mouth such as breathing through the mouth, a completely different balance of forces adversely affecting the skeleton of the lower part of the face and dental arches is formed. ${ }^{32}$ Theory of growth and development of craniofacial skeletal structures of Moss $^{35}$ assumes that the maxillary and mandibular bone is surrounded by a "functional matrix". The composition of this matrix includes: muscles, glands, nerves, blood, and fat. There are two types of functional matrix: periosteal and capsularis matrix. The relationship of functional matrix and alveolar bone is another example to support "form-function" relationships. An example could be the impact of the temporal muscle on the growth and development of the condyle. In experimental studies on mammals, where the temporal muscle was removed or it was de-nerved, it resulted in the gradual disappearance and change in the shape of the condyle, and even the complete disappearance of the condyle. In contrast, the temporal muscle overactivity caused an increased condyle or a change in its shape.

When planning the orthodontic treatment it is very important to carefully examine the aetiology of widłowego rozwoju łuków zębowych i całej twarzoczaszki. W literaturze wielu autorów uznaje, że im wcześniej powróci prawidłowa funkcja, tym łatwiej i szybciej, a nawet samoistnie bez terapii aparatem ortodontycznym, możliwe jest cofnięcie się wady zgryzu powstałej na tle dysfunkcji. ${ }^{1,29,33}$ Należy podkreślić fakt, że w przypadku zaburzonej funkcji mięśni otaczających szparę ustną, jak np. w oddychaniu przez usta, powstaje całkiem inny układ sił wpływający niekorzystnie na rozwój szkieletu dolnej części twarzy oraz łuków zębowych. ${ }^{32}$ Teoria wzrostu i rozwoju struktur szkieletu twarzoczaszki Mossa ${ }^{35}$ zakłada, że kości szczęki i żuchwy otoczone są przez „matrycę czynnościową". W skład tej matrycy wchodzą: mięśnie, gruczoły, nerwy, naczynia, tłuszcz. Istnieją dwa rodzaje matrycy czynnościowej: matryca okostnowa i torebkowa. Relacja typu matryca czynnościowa - kości wyrostków zębodołowych, to kolejny przykład popierający relacje forma-funkcja. Przykładem może być wpływ czynności mięśnia skroniowego na wzrost i rozwój wyrostka kłykciowego. W badaniach eksperymentalnych u ssaków, gdzie usunięto mięsień skroniowy lub go odnerwiono, rezultatem był stopniowy zanik oraz zmiana kształtu wyrostka kłykciowego, a nawet całkowity zanik wyrostka. Natomiast nadaktywność mięśnia skroniowego powodowała zwiększenie wyrostka kłykciowego lub zmianę jego kształtu.

W planowaniu leczenia ortodontycznego bardzo ważne jest dokładne zbadanie etiologii wady zgryzu, ponieważ wiadomo, że inne podejście do leczenia należy zastosować w przypadku wad powstałych na tle dysfunkcji (dysfunkcja języka lub oddychania), a inne dla wad pochodzenia morfogenetycznego. ${ }^{2}$ Wcześnie uzyskane informacje o występowaniu nieprawidłowego toru oddychania wraz z dysfunkcją języka, dają możliwość prowadzenia działań profilaktycznych. W ortodoncji profilaktyka polega na właściwym kierowaniu wzrostem i rozwojem już od wczesnego dzieciństwa. W profilaktyce niezmiernie ważna jest rola rodziców, którzy powinni współpracować z ortodontą. Czasami konieczna jest również współpraca $\mathrm{z}$ innymi specjalistami, w celu wyeliminowania przyczyn nieprawidłowego toru oddychania. Dlatego w razie wątpliwości należy 
malocclusion, sinceitiswidelyknownthatadifferent approach to treatment should be applied in the case of defects arising in connection with dysfunction (tongue or breathing dysfunction), and another for malocclusion of the morphogenetic origin. ${ }^{2}$ Early received information about the presence of abnormal breathing with tongue dysfunction, makes it possible to carry out preventive activity. In orthodontics, prevention involves proper management of growth and development from early childhood. In the prevention stage the role of parents/carers who should cooperate with the orthodontist is extremely important. Sometimes it is also necessary to work with other specialists in order to eliminate the causes of abnormal respiratory course. Therefore, in the case of any doubt young patients should be referred to an ENT specialist. Re-education in orthodontics has a very long history and is one of the oldest methods of preventing malocclusions. Early used in qualifiable group of patients (only those defects that arise from functional disorders) are often enough to completely eliminate malocclusion. Certainly big downside of this method is close patient-orthodontist-parent cooperation. Trainertype functional elastic standard appliances are a good, helpful, inexpensive and simple "tool" that can be used in the re-education of young patients. These appliances are very well received by them and used willingly. Handled correctly, re-education with the use of Trainers will give a good chance to prevent malocclusion arising from dysfunction.

\section{Summary}

In this study, a positive impact of Trainertype functional elastic standard appliance on the function of breathing (breathing through the mouth - habitual) and the position of the tongue during swallowing was found. In patients with skeletal open bite tongue dysfunction is the result of adaptive effect (front seal) and only complete treatment of malocclusion will eliminate that dysfunction.

\section{Concusions}

Treatment of Class II division 1 with the kierować małych pacjentów na konsultację z laryngologiem. Reedukacja $w$ ortodoncji ma bardzo bogatą historię i jest to jedna $z$ najstarszych metod zapobiegania wadom zgryzu. Wcześnie zastosowana, w odpowiedniej grupie pacjentów (tylko wady powstające na tle zaburzeń czynnościowych), często wystarczy do całkowitego wyeliminowania wady zgryzu. Metoda ta wymaga ścisłej współpracy pacjenta, lekarza i rodzica. Aparaty elastyczne standardowe typu Trainer są bardzo dobrym, pomocnym, niedrogim i prostym „narzędziem”, który możemy zastosować w reedukacji małych pacjentów. Te aparaty są bardzo pozytywnie odbierane przez małych pacjentów i chętnie noszone. Prawidłowo prowadzona reedukacja z zastosowaniem Trainerów daje duże szanse na zapobieganie wadom zgryzu powstających na tle dysfunkcji.

\section{Podsumowanie}

W niniejszym badaniu potwierdzono pozytywny wpływ aparatów elastycznych standardowych typu Trainer na czynność oddychania (oddychanie przez usta nawykowe) oraz pozycję języka w trakcie czynności połykania. U pacjentów ze zgryzem otwartym szkieletowym dysfunkcja języka jest efektem adaptacyjnym (uszczelnienie przednie) i jedynie całkowite wyleczenie wady umożliwia wyeliminowanie tej dysfunkcji.

\section{Wnioski}

Leczenie wad klasy II podgrupy 1 o etiologii czynnościowej (dysfunkcja języka, oddychanie przez usta nawykowe, hipotonia mięśnia okrężnego ust, ,pułapka wargowa”) aparatem standardowym, elastycznym typu Trainer przez okres 12 miesięcy wraz z odpowiednią mioterapią wpływa pozytywnie na czynność mięśnia okrężnego ust oraz czynność języka, a co za tym idzie, wpływa korzystnie na poprawę relacji zębowo-wyrostkowych - zmniejszenie nagryzu poziomego poprzez cofnięcie zębów siecznych górnych i nieznaczne wychylenie zębów dolnych wraz z wyrostkiem.

Zastosowanie aparatów standardowych elastycznych u pacjentów z wadą klasy II podgrupy 1 oraz ze zgryzem otwartym o charakterze szkie- 
functional etiology (tongue dysfunction, habitual mouth breathing, orbicular oris hypotonia, "lip trap") by means of Trainer-type functional elastic standard appliance during the period of 12 months with appropriate myotherapy has a positive effect on the function of orbicular oris and tongue function, and thus has a beneficial effect on improving dentoalveolar process relations by reducing overjet by retrusion of the upper incisors and slight proclination of the lower incisors with their alveolar processes.

The use of standard elastic appliances in patients with Class II division 1 and with skeletal open bite treated before peak of growth spurt has no significant effect on skeletal relations.

The use of Trainer-type standard elastic applainces among patients with dental open bite arising from the tongue dysfunction and/or against mouth breathing has a positive effect on the improvement of tongue function and respiration, and reduces overbite.

Miofunctional therapy with the use of Trainertype standard elastic appliances has a beneficial effect on the function of orbicular oris and tongue during swallowing and breathing and on lips competence.

This study confirms that the Trainer-type elastic appliances cause changes in overjet and overbite exclusively through dentoalveolar changes, therefore, proper selection of patients for treatment with these appliances is very important. It should be emphasized that therapy with these appliances should only be conducted in the period of milk and mixed dentition and with acquired dysfunctions and parafunctions of the masticatory system.

Trainer-type standard elastic appliances are easy to use, well accepted and gladly worn by young patients. Applied for two hours per day and night they give a satisfactory therapeutic effect. They can be used as part of interceptive orthodontics and early orthodontic treatment for functional disorders such as infantile type of swallowing, habitual mouth breathing, and in the case of parafunctions such as sucking a pacifier, sucking fingers, biting lips or nails. letowym leczonych przed skokiem wzrostowym nie ma istotnego wpływu na relacje szkieletowe.

Zastosowanie aparatów standardowych, elastycznych typu Trainer u pacjentów ze zgryzem otwartym zębowo-wyrostkowym powstałym na tle dysfunkcji języka lub/i na tle oddychania przez usta wpływa pozytywnie na poprawę funkcji języka i oddychania oraz zwiększenie nagryzu pionowego.

Miofunkcyjna terapia z zastosowanie aparatów standardowych, elastycznych typu Trainer wpływa korzystnie na czynność mięśnia okrężnego ust i języka w trakcie połykania i oddychania oraz na kompetencję warg.

Powyższe badanie potwierdza, że aparaty elastyczne typu Trainer wpływają na zmianę nagryzu poziomego i pionowego wyłącznie poprzez zmiany zębowo-wyrostkowe, dlatego bardzo ważny jest odpowiedni dobór pacjentów do leczenia tymi aparatami. Należy podkreślić że terapia tymi aparatami powinna być prowadzona jedynie $\mathrm{w}$ okresie uzębienia mlecznego i mieszanego oraz w wadach nabytych wywołanych dysfunkcjami i parafunkcjami narządu żucia.

Aparaty standardowe, elastyczne typu Trainer są aparatami łatwymi w użyciu, akceptowanymi i chętnie noszonymi przez małych pacjentów. Zastosowane przez dwie godzinny dziennie i noc dają zadowalający efekt terapeutyczny. Mogą być zastosowane jako element profilaktyki ortodontycznej i wczesnego leczenia ortodontycznego w przypadku zaburzeń czynnościowych typu przetrwały niemowlęcy typ połykania, oddychanie przez usta nawykowe oraz w przypadku parafunkcji typu: ssanie smoczka, palców, nagryzanie warg czy obgryzanie paznokci. 


\section{References}

1. Garliner D: Myofunctional therapy in dental practice. Philadephia: Saundrs; 1973. p. 164-180.

2. Graber MT, Rakosi T, Pertovic A: Aparaty czynnościowe w ortopedii szczękowo-twarzowej. Lublin: Wydawnictwo Czelej; 2001. p. 170-174.

3. Kawala B, Babczuk T, Czekańska A: Występowanie dysfunkcji, parafunkcji i wad narządu żucia u dzieci w wieku przedszkolnym. Dent Med Probl 2003; 40: 319-325.

4. Posen AL: The influence of maximum perioral and tongue force on the incisor teeth. Angle Orthod 1972; 42: 285-309.

5. Melsen B, Attina L, Santuari M, Attina A: Relationships between swallowing pattern, mode of respiration, and development of malocclusion. Angle Orthod 1987; 57: 113-120.

6. Kasparaviciene K, Sidlauskas A, Zasciurinskiene $E$, vasiliauskas $A$, Juodzbalys $G$, Sidlauskas $M$, marmaite $U$ : The Prevalence of Malocclusion and Oral Habits among 5-7 Year Old Children. Med Sci Monit 2014; 20: 203602042.

7. Dyck C, Dekeyser A, Vantricht E, Manders E, Goeleven A, Fieuws S, Willems G: The effect of orofacialmyofunctional treatment in children with anterior open bite and tingue dysfunction: a pilot study. Eur J Orthod 2015; 1: 1-8.

8. Yamaguchi H, Sueishi K: Malocclusion associated with abnormal posture. Bull Tokyo Dent Coll 2003; 44: 43-54.

9. Tallgren A, Chirstiansen RL, Ash MM, Miller RL: Effects of a myofunctional appliance on orofacial muscle activity and structures. Angle Orthod 1998; 68: 249-258

10. Proffit WR, Mason RM: Myofunctional therapy for tongue-thrusting: background and recommendations. J Am Dent Assoc 1975; 90: 403410.

11. Tehereh J, Farzaneh A, Foroozandeh A: Effect of Tongue Thrust Swallowing on Position of Anterior Teeth. J Dent Res Dent Clin Dent Prospects 2009; 3: 73-77.

12. Subtelny DJ, Subtelny JD: Oral Habits-Studies in Form, Function, and Therapy. Angle Orthod 1973; 43: 349-383.

13. Subtelny DJ: Malocclusions, Orthodontic Corrections and Orofacial Muscle Adaptation. Angle Orthod 1970; 40: 170-201.

14. Brauer JS, Holt TV: Tongue thrust classification. Angle Orthod 1965; 35: 106-112.
15. Yagci A, Uysal T, Kara S, Okkesim S: The effects of myofunctional appliance treatment on the perioral and masticatory muscles in class II, division 1 patients. Word J Orthod 2010; 1: 117-122.

16. Tulley WJ: A critical appraisal of tongue-thrusting. Am J Orthod 1969; 55: 640-650.

17. Łyszczarz J, Szot $W$, Loster $B W$ : Zależność między ustnym torem oddychania a częstością wystepowania wad zgryzu i sprawnościa wentylacyjną u dzieci w okresie dojrzewania. J Stoma 2012; 65: 714-728.

18. Kustrzycka K, Jaworska M: Wpływ schorzeń górnych dróg oddechowych na wady zgryzu. Czas Stomat 1997; 50: 47-54.

19. Downarowicz P, Matthews-Brzozowska T: Wpływ schorzeń górnych dróg oddechowych na wady zgryzu -przegląd piśmiennictwa. Twój Prz Stomatol 2007; 6: 45-49.

20. Williams $S$, Loster $B W$ : Cephalometrics rationalized: Presenting the Krakovia Composite System (KCS). J Stoma 2012;65: 525-542.

21. Souki BQ, Pimenta GB, Souki MQ, Franco LP, Becker $M G$, Pinto JA: Prevalence of malocclusion among mouth breathing children: Do expectations meet reality?Int J Pediatr Otorhinolar 2009; 73: 767-773.

22. Lofstrand-Tidestrom B, ThilanderB, AhlqvistRastad J, Jakobson O, Hultcrantz E: Breathing obstruction in relation to craniofacial and dental arch morphology in 4-year-old children. Eur J Orthod 1999; 21: 323-332.

23. Giuca MR, Pasini M, Galli V, Casani AP, Marchetti E, Marzo G: Correlations between transversal discrepancies of the upper maxilla and oral breathing. Eur J Paediatr Dent 2009; 10: 23-28.

24. Ovsenik M, Farcnik FM, Korpar M, Verdenik I: Follow-up study of functional and morphological malocclusion trait chan ges from 3 to 12 years of age. Eur J Orthod 2007; 29: 523-529.

25.Dimberg L, Lennartsson B, Soderfeldt B, Bondemark L: Malocclusions in children at 3 and 7 years of age: a longitudinal study. Eur J Orthod 2013; 35: 131-137.

26. Gois EG, Ribeiro-Junior HC, Vale MP, Paiva SM, Serra-Nagra JM, Ramos-Jorge ML, Pordeus $I A$ : Influence of nonnutritive sucking habits, breathing pattern, adenoid size on development of malocclusion. Angle Orthod 2008; 4: 647-654.

27. Tourne $L$ : The long face syndrome and impairment 
of the nasopharyngeal airways. Angle Orthod 1990; 60: 167-176.

28. Goldsmith JL, Stool SE: George Catlin's koncept on mouth-breathing, as presented by Dr Edward H. Angle. Angle Orthod 1994; 64: 75-78.

29. Cheng $M C$, Enlow DH: Developmental effects of impaired breathing in the face of the growing child. Angle Orthod 1988; 58: 309-320.

30. Paul JL, Nanda RS: Effect of Mouth Breathing on Dental Occlusion. Angle Orthod 1973; 43: 201206.

31. Quinn GW: Air Interference Syndrome. Angle Orthod 1983; 53: 311-319.

32. Rubin MR: Facial Deformity: A Preventable Disease? Angle Orthod 1979; 49: 98-103.

33. McNamara JA: Influence of Respiratory Pattern On Craniofacial Growth. Angle Orthod 1981; 51:
269-300.

34. Brader $A C$ : Dental arch form related with intraoral for ces $\mathrm{PR}=\mathrm{C}$. Am J Orthod 1972; 60: 541-561.

35. Moss ML, Salentijn L: The primary role of functional matrices in facial growth. Am J Orthod 1969; 55: 566-577.

36. Howe RP, McNamara JA, O'Connor KA: An examination of dental crowding and its relationship to tooth size and arch dimension. Am J Orthod 1983; 83: 363-373.

Address: 31-155 Kraków, ul. Montelupich 4 Tel.: +4812 4245402, Fax: +48124245494

e-mail: bwloster@gmail.com

Received: $25^{\text {th }}$ April 2016

Accepted: $7^{\text {th }}$ January 2017 